\title{
THE CONTRIBUTION OF READING ACTIVITIES TOWARDS THE STUDENTS WRITING PERFORMANCE
}

\author{
Yanpitherzon Liunokas \\ yanliunokas@yahoo.co.id \\ Universitas Nusa Cendana
}

\begin{abstract}
Reading activities in this paper includes the habit of students in reading in their daily lives such as reading books, magazine, articles, online news and articles etc. Writing performance is the ability of students in expressing their ideas in written forms or paragraph. The aimed of the research is to find out the contribution of reading activities towards the students writing performance. This research applied descriptive method to describe the correlation between the reading activities and the students' ability in writing. This research was conducted at SMAN 1 Soe, Kabupaten Timur Tengah Selatan (TTS), NTT. Findings of the research show that the reading habits of students have significant contribution towards the students' writing ability. Mean score the reading is 81.13 and standard deviation is 8.26 and writing mean score is 68.93 and standard deviation is 8.12 . The correlation test using Pearson Product Moment with SPSS 20 software program found that the score of significance is 991 , which is higher than $\alpha$ score $(991 \geq 07)$, is classified as a good correlation. It indicates that when the students have a good reading habit, it will give good contribution towards their competence in writing.
\end{abstract}

Keywords: reading activities, writing performances, correlation

\begin{abstract}
Abstrak
Kegiatan membaca yang dibahas pada makalah termasuk bahan yang biasa dibaca oleh siswa sehari-hari, misalnya buku, majalah, artikel, berita online, dan sebagainya. Adapun kemampuan membaca adalah kemampuan siswa dalam mengekspresikan ide dalam bentuk paragraf. Tujuan penelitian ini adalah menemukan pengaruh kegiatan membaca siswa terhadap kemampuan menulisnya. Peneliti menggunakan metode desktiptif untuk menjelaskan korelasi antara kegiatan membaca dengan kemampuan siswa dalam menulis. Penelitian ini diadakan di SMAN 1 Soe, Kabupaten Timur Tengah Selatan, NTT. Hasil temuan menunjukkan pengaruh signifikan kegiatan membaca terhadap kemampuan menulis. Rata-rata skor Reading 81.13 dengan standar deviasi 8.26, sedangkan ratarata skor Writing 68.93 dengan standar deviasi 8.12. Uji korelasi dengan Pearson Product Moment pada aplikasi SPSS 20 menunjukkan skor signifikansi 991, lebih tinggi dari $\alpha(991 \geq 07)$, yang berarti berkorelasi positif. Hal tersebut menunjukkan bahwa ketika siswa punya kebiasaan membaca yang baik, maka akan berpengaruh positif terhadap kemampuan mereka dalam menulis.
\end{abstract}

Kata kunci: kegiatan membaca, kemampuan menulis, korelasi 


\section{Background}

Reading activity is needed to master many things in our life, including English. It is because reading can help the learners of English to understand the language. Reading is a key when we want to get some information from English books, magazine, newspaper, internet, study science and technology and many other sources. In addition, reading is a source of getting information. No one, can get many information without reading. By reading, the students can improve their vocabulary and understand some other aspects of language. Wooding Keith Johnson stated that we read in order to obtain information which is presented in the written form, but by nature of the information so obtained require more explicit definition. He further explains "by referential (factual), affective or emotional, so then:

1. Answer we can give to our question, of why we read is that we read referential material in order to obtain factual information with operating on our environment, e.g. a set of instruction or how to use a piece of equipment.

2. We read as a way of developing our own intellectual skill, so that we can more effectively manipulate ideas, possibly with the aim of influencing the behavior of others of determining the outcome of series of operations, e.g. making proposal for project.

3. We read for emotional gratification or spiritual enlightenment, e.g. for pleasure or self-environment.

There are many interesting sources or media that can be read by students, such as story, novel, science books, encyclopedia, autobiography etc. Some reading sources are not only a means of entertaining, but also a means of sending massage to the readers. The message delivered may include artistic aspect, economic aspect, cultural aspect and human aspect, which are worldwide along with modern life.

One of the skills in English which can be influenced by reading activities is writing. Writing is one of the ways that we translate our thoughts for other people. Some people are better at expressing themselves in writing than any other way, and someone thus get a better translation when she/he reads what they have to say rather than hearing them speak (Nunan, 2003:89). 
Writing assists people with other language tasks as well writing helps us learn how to form language, how to spell, how to put together a plot. Someone learns how to make a logical argument, or how to persuade, mainly through writing. Speaking can help you learn those things as well, but it is easier to self-examine and evaluate how to improve when you have something concrete in front of you, and can revise. The written and structure expression includes two questions because if we want to write something we must attention good of grammar in other that our article in English be an excellent (Hadley, 1996:290)

Writing is the mental work of inventing ideas, thinking about how to express them, and organizing them into statements and paragraphs that will be clear to a reader. Writing is a one way to develop our opinions, ideas or thoughts. According to Widdowson (2005:61) on describe that writing is the act of making up correct sentence and transmitting them through visual medium to manifest the graphology and grammatical system of the language. According to Manser (1995:480), writing is the activity or occupation of writing for instance books, stones, and article. Writing is a physical act of committing words or ideas, thinking about how to express them, and organizing them into statements and paragraphs. Writing skill is a key indicator of language ability and basic ability for studying various subject it influence to significance action nations, quality and educational performance. As conclusion, it can be said that writing skill is a skill which is related to the effort the effort of expressing ideas into written forms. It also related to the ability of someone to construct sentences and paragraph.

Teaching writing as a foreign language is to get learner to acquire the abilities and skills. Alice Omaggio Hadley point out writing as a support skill and writing as a communication art parallels, to some extents (Hadley, 1996:291). Writing skill includes in two categories of activities: (1) Writing down, or exercise involving copying or reproduction of learned material, concentrating on the conventions of spelling, punctuation, grammatical agreements, etc. and (2) Writing in the language, which students engage in a variety of grammar practice activities of the controlled nature in order reinforce their growing knowledge of the linguistic system because of writing is productive skill and creative or expressive writing. So, rivers describe that creative or expressive writing includes in two categories: (1) 
Flexibility measures, in which student begin writing within a framework (including transformation exercise, sentence combining practice, expressions embellishments, idea frames, and similar activities. (2) Expressive writing, which includes guided and free compositions that fulfill the normal purposes for which we write in the real word (Hadley, 1996:291).

In this research, the writer explains about the contribution of reading activities towards writing performance. The result of this research is expected to be useful: For the teacher, to obtain feedback and information on the importance of reading activities towards students' writing performance. For the students, to obtain information that is useful as an input to further implement the reading activities in order to improve student' writing skill. For the reader, to obtain information in order to add insight and input on the importance of reading activities and writing achievement. In this research the researcher focuses on the contribution of the students' reading activities in their daily life such as reading magazine, articles both printed or online, novel etc. towards their achievement in writing especially the content, vocabulary, language use, organization and mechanics at SMAN 1 Soe, Kabupaten Timur Tengah Selatan (TTS), NTT.

\section{Research Method}

This research applied descriptive method. The aim was to describe the correlation between the reading activities and the students' ability in writing. This research was conducted in August 2014 and this research will be conducted at the second year students of SMAN 1 Soe, Kabupaten Timur Tengah Selatan (TTS), NTT. The population of research was the second year students, and 15 students were selected as sample of this research. The instrument of this research used writing test and questionnaire. The writing test was in the form of narration. In the writing test, the students showed their ability in writing. Then the questionnaire was used to observe the students reading activities. 


\section{Findings and Discussion}

Correlation between questionnaire and result of students' writing it can be seen on the table below:

Table 1. Result of questionnaire and writing test

\begin{tabular}{llll}
\hline No & Sample Name & $\begin{array}{l}\text { Students' Reading Habits } \\
\text { (Questionnaire) }\end{array}$ & $\begin{array}{l}\text { Students' } \\
\text { Writing Score }\end{array}$ \\
\hline 1 & WPI & 84 & 80 \\
2 & FDI & 73 & 73 \\
3 & RMG & 79 & 62 \\
4 & UFA & 87 & 74 \\
5 & MK & 80 & 75 \\
6 & UKM & 68 & 82 \\
7 & MDS & 88 & 68 \\
8 & DF & 76 & 61 \\
9 & HH & 72 & 61 \\
10 & FS & 87 & 62 \\
11 & HM & 76 & 61 \\
12 & HN & 85 & 61 \\
13 & DIS & 92 & 61 \\
14 & WG & 87 & 80 \\
15 & DA & 73 & 73 \\
\hline
\end{tabular}

Table shows that there are 15 name of respondents which the researcher explain that the reading habits is variable $\mathrm{X}$ and students writing is variable $\mathrm{Y}$. The researcher found that the result of questionnaire on reading habits (variable $\mathrm{X}$ ) was 1207 and the students' writing score (variable Y) was 1034.

The following table is SPSS result, the researcher found the result of correlation between students' reading habits and students writing.

Table 2. Descriptive statistics

\begin{tabular}{lcllll}
\hline & $\mathrm{N}$ & Minimum & Maximum & Mean & Std. Deviation \\
\hline Reading Habits & 15 & 8.00 & 97.00 & 81.1333 & 8.26236 \\
Writing score & 15 & 61.00 & 82.00 & 68.9333 & 8.11935 \\
Valid N & 15 & & & & \\
(list wise) & & & & & \\
\hline
\end{tabular}

Table 2 shows that or total sample is 15 , questioner about reading Habits get score minimum 80 , maximum 97 , mean score is 81.13 and standard deviation is 8.2. Students' writing score get minimum 61.00, maximum 82.00, mean score 68.93 and standard deviation 8.1. 
Table 3. Correlation between Reading Habits and Students' writing score

\begin{tabular}{llll}
\hline & & Reading Habits & Writing score \\
\hline \multirow{4}{*}{ Reading Habits } & Pearson Correlation & 1 & 0.03 \\
& Sig. (2-tailed) & & 991 \\
& $\mathrm{~N}$ & 15 & 15 \\
& Pearson Correlation & 0.03 & 1 \\
Writing score & Sig. (2-tailed) & 991 & \\
& $\mathrm{~N}$ & 15 & 15 \\
\hline
\end{tabular}

Based on table 3, it can be seen that the score significance is 991 . The score significance is higher than $\alpha$ score $(991 \geq 07)$. It means that there is a good contribution based on the classification of coefficient contribution (60-79) is good classification. It indicates that when the students have good reading habits, it was have good contribution towards their competence in writing.

After analyzing the data at the findings, the researcher presents the discussion of data. In this section, the researcher presents the result of data analysis and relates it to the theory in review of related literature in chapter II. Furthermore, this section aimed at describing the contribution of the reading habits towards the students' writing score.

This research proves that when the students have good reading habits, it was have good contribution towards their competence in writing. It is supported by the data analysis by using statistics in which the data from the questionnaire about reading habits is correlated with their achievement in reading. In the questionnaire it is found that about $93 \%$ students agree that they reading in free time. Then, it is also found that most of the students $83.7 \%$ agree that they always read academic article or related to the lesson. In other hand, $74 \%$ of the students agree that they also always read books such as novel and folktale. This indicates the students have good habits in reading. The good reading habits also supported by the data $43.3 \%$ students who always reading newspaper. Related to the habits in reading, $60.7 \%$ of the students always do not taking while reading. $60 \%$ students spend their times by reading. $73.3 \%$ of the students agree that they prefer reading than watching TV $80 \%$ of the students agree that they reading online article. $73.3 \%$ students agree that they prefer to browsing and searching online reading. The data of reading habits shows 
that the students at SMAN 1 Soe, Kabupaten Timur Tengah Selatan (TTS), NTT have read the academic and non-academic text.

Related to importance of reading, $73 \%$ students agree that reading is very important in learning English and $86.7 \%$ of the students agree that reading is interesting. This data shows that the students have positive attitude towards the importance of reading. It means only $40 \%$ of the students agree that reading is not boring. $73.3 \%$ of the students agree that reading can increase vocabulary. $66 \%$ of the students agree that reading can help in learning English. This finding in line with the expert statement namely Wooding Keith Johnson in Yasmir, who states that we read in order to obtain information which is presented in the written form, but by nature of the information so obtained require more explicit definition.

The data from the students writing, it is found that the students still have some difficulties in writing. It is found that the highest score of students was 82 . Then, the lowest score of students in writing was 61, the mean score 68.93 and standard deviation 8.1 In addition, many of students still got difficulties in writing. They still face problem with the five criteria given in writing evaluation. In content, some students got problem since they have very limited vocabulary and less reading. In addition, many students still face problem with grammar and organization

\section{Conclusion}

Based on the findings and discussion at the previous chapter, the researcher can conclude that the reading habits of students have significant contribution towards the students' writing ability. Mean score the reading 81.1333 and standard deviation 8.26236 and writing mean score 68.9333 and standard deviation 8.11935. Also it was supported by the result of the correlation test using Pearson Product Moment with SPSS 20 software program, it is found that the score significance is 991. The score significance is higher than $\alpha$ score $(991 \geq 07)$. It is classified as a good correlation. It is based on the classification of coefficient correlation (60-79). It indicates that when the students have a good reading habits, it was having good contribution towards their competence in writing. Reading habits of some can give good influence on the students' performance. 


\section{References}

Beare, K. (1997). Reading comprehension skills-Scanning/Skimming and Scanning. (online).

Brown, H. D. (1994). Principles of Language Learning and Teaching. 3rd Edition, New Jersey: Prentice Hall.

Burns, P. (1984). Teaching by Principle. Second edition. San Francisco State University.

Clenton, J. (1951). Academic Writing towards and Integrated Approach http://www.sussex.ac.uk/languagedocument

David, N. (1976). Practical English Language Teaching, (International Editor, USA), p. 88.

George E. W. \& Burks, J. M. (1980). Let's Write English. New York.

Gay, L. (1981). Educational Research Competence for Analysis and Application. Second Edition. Florida International University.

Heaton. J. B. (1988). Writing English Language Test. New York: Longman.

Manser, M. H. (1995). Oxford Learners Pocket Dictionary. New Edition. New York: Oxford University Press.

Mikulecky, B. (1987). Reading power (Reading Faster, Thinking Skill Reading for Pleasure, Comprehension Skils). Bastom University Linda Jeffries. Addition-Wesky Publishing Company.

Nunan, D. (1992). Collaborative Language Learning and Teaching. Cambridge: Cambridge University Press.

Roslyin, P. \& Marsha, D. (1994). The Professional Writing Guide: Writing Well and Knowing Why. Second Edition. Australia: Longman Professional.

Sutanto, L. (2007). Essay Writing English for Academic Purpose. Yogyakarta: CV. Andi Offset.

Widdowson, H. G. (2005). Teaching Language as Communication. New York: Oxford University Press.

O’Grady, W. (1997). Contemporary Linguistics: An introduction. Third edition. New York: St. Martin's Press.

Walker, B. J. (1996). Teaching of Reading for Instruction and Assessment. (Online) http://www.siu.ed/arc.html Retrieved on 7 November 2015. 